\title{
What cell wall components are the best indicators for Miscanthus digestibility and conversion to ethanol following variable pretreatments?
}

\author{
J. M. M. Adams ${ }^{1 *}$, A. L. Winters' ${ }^{1}$ E. M. Hodgson² and J. A. Gallagher ${ }^{1}$
}

\begin{abstract}
Background: Energy crops including Miscanthus provide a storable, portable energy source which can be used to complement a wide range of products and energy generation systems. Miscanthus is predominantly used in Europe as a combustion material for electricity generation but also has the potential for biochemical conversion due to its high yield and low-nutrient requirements. The ratio of holocellulose (hemicellulose and cellulose combined) to acid detergent lignin (H:L) within the senesced material has previously been shown to indicate the relative suitability of Miscanthus accessions for thermochemical conversion. In this study, the ratio was assessed to examine its use as a selection aid for biochemical conversion. 20 highly-characterised Miscanthus accessions were saccharified using an enzyme mix to determine optimum sugar release. Nine of these accessions spanning high, medium and low H:L ratios were then autoclaved with dilute acid, alkali or water, and enzymically hydrolysed and fermented to produce ethanol. Samples taken throughout the process allowed assessments of released sugars.
\end{abstract}

Results: Enzymic degradation of the biomass showed a relationship between H:L ratio and glucose release, with high glucose release for high H:L ratio accessions and vice versa. Xylose release showed no such relationship. This relationship was maintained following pretreatments and enzyme saccharification, where compound analysis showed that following all pretreatments, accessions with high $\mathrm{H}: \mathrm{L}$ ratios repeatedly had the highest releases of glucose, xylose and arabinose, and produced more ethanol. Release of all measured compounds increased with the pretreatment severity and ethanol yields from each pretreatment correlated with the respective glucose yield, providing assurance that any inhibitory compounds generated were tolerated by the fermentation yeast. Strong correlations were also seen between glucose release, ethanol and cell wall components, with cellulose showing the highest correlations with ethanol yields for some treatments and $\mathrm{H}: \mathrm{L}$ ratio with others.

Conclusions: The H:L ratio is a good predictor of ethanol yields and sugar release from Miscanthus in this study but individual components lignin and cellulose also correlate well, especially for hot water and mild acid pretreatments. In conclusion, use of the H:L ratio does not provide any advantages over the concentration of individual cell wall components for predicting sugar release and ethanol yields.

Keywords: Bioethanol, Biofuel, Biorefining, Cellulose, Dilute acid, Energy crop, Miscanthus giganteus, Hemicellulose, Lignocellulosic, Saccharification

\footnotetext{
*Correspondence: jaa@aber.ac.uk

${ }^{1}$ Institute of Biological, Environmental and Rural Sciences, Aberystwyth

University, Gogerddan, Aberystwyth SY23 3EE, UK

Full list of author information is available at the end of the article
} 


\section{Background}

Tackling anthropogenic climate change can only be achieved by replacing fossil-fuel products with a multitude of low-carbon alternatives for generating energyand carbon-based products. The use of biomass provides a storable, portable energy source which can be processed to complement many existing power and product generation systems. One source of biomass is the 'energy crops', high-yielding crops with low moisture content at harvest [1], which grow well on sub-optimal land with low fertiliser demands [2]. Within these requirements, the perennial grasses from Asia in the genus Miscanthus [3] have been identified as an energy crop with global potential [2], with some $M$. sinensis hybrids producing up to $41 \mathrm{t} \mathrm{Ha}^{-1} \mathrm{yr}^{-1}$ [4]. The high-yielding sterile triploid hybrid Miscanthus $x$ giganteus has been particularly investigated for its compositional qualities including applications in paper, building materials, geotextiles and greenhouse substrate production [5].

Miscanthus harvesting occurs once the plant has senesced (typically following the first autumn frost) and is harvested early the following year. This reduces moisture content, ash and elemental components [1] through the translocation of nutrients from the aboveground plant to the rhizomes during senescence [6]. This produces a feedstock with more desirable biomass processing properties such as a lower reactive alkali metal content and a reduced drying requirement [7], despite a concurrent yield loss compared to peak yield attributed to leaf loss [5], with leaves contributing approximately one-third of the total biomass in Miscanthus [8].

Though the predominant use of Miscanthus in Europe is currently for energy generation through combustion [7], its high yields mean it should also be considered for biochemical conversion, including the production of liquid biofuels and platform chemicals. To produce these products from Miscanthus, the biomass needs to be hydrolysed to release soluble fermentable sugars from the cell wall for conversion by yeast to produce ethanol under anaerobic conditions or other microorganisms to produce a range of chemicals. Spring harvested (senesced) Miscanthus will typically contain $70-90 \%$ cell wall $(w / w)[9,10]$, with cellulose, hemicellulose and lignin as the main compounds present. Cellulose and hemicellulose, collectively termed holocellulose, can be hydrolysed to release a number of $\mathrm{C} 5$ and $\mathrm{C} 6$ sugars with the main forms being xylose and glucose, respectively [3]. Lignin is a complex aromatic polymer which forms a protective barrier within the cell wall around the hemicellulose and cellulose [11], making the lignocellulosic material generally recalcitrant to enzymic conversion [12] unless physiochemical pretreatments are used. Pretreatments include ammonia fibre explosion (AFEX) and other chemical treatments, biological treatments and steam explosion [13]. All treatments alter the lignocellulosic structure [11] by increasing the material porosity, either through the removal of lignin or hemicellulose; or by a reduction in cellulose crystallinity [5]. The ratio of holocellulose to lignin $(\mathrm{H}: \mathrm{L})$ has previously been shown to indicate the suitability of Miscanthus for thermochemical conversion [14], and work below applied this concept to biochemical conversion, using the ratio as a selection criteria for the Miscanthus lines used in this study.

Our research used two common thermochemical pretreatment techniques, dilute acid and alkali pretreatments, both applied with increased temperatures and pressures. Dilute acid is more attractive to industry than concentrated acid due to a reduction in its corrosion, toxicity and inhibitor production [13]. Dilute acid pretreatments primarily hydrolyse the hemicelluloses, though strong acids can also break cellulosic bonds, releasing glucose monomers [15]. Two types of dilute acid pretreatments are typically conducted in studies: a low solids (5-10\%), high-temperature $\left(T>160{ }^{\circ} \mathrm{C}\right)$ continuous flow process and a high solids (10-40\%), low-temperature $\left(T<160{ }^{\circ} \mathrm{C}\right)$ batch process [11] with work described in this paper categorised as the latter. During acid pretreatments, inhibitors may also be formed which are detrimental to downstream processing [3]. At high temperatures, inhibitors such as furfural can also degrade, forming formic and levulinic acids [13] which further reduce the $\mathrm{pH}$ and increase inhibition.

Alkali pretreatments break ester bonds which crosslink lignin and hemicellulose, solubilising lignin molecules and increasing enzyme access to the cellulose [15]. It also partially decomposes the hemicellulose and weakens the hydrogen bonds between cellulose fibrils, reducing the crystallinity and enabling swelling to occur, in turn increasing the surface area of the cellulose [16].

These alkali pretreatments show less sugar hydrolysis than that seen in acid pretreatment processes and have a lower operations cost as the reactor vessel is not subjected to corrosion as with acid [17]. Of the main alkaline pretreatments used (ammonia, sodium, potassium and calcium hydroxide), calcium hydroxide is the least expensive and can be recovered and regenerated using carbon dioxide and established lime kiln technologies [18]. Residues can also be used as soil conditioners with calcium an important macro-nutrient [16]. Calcium hydroxide treatments are effective at delignifying low-lignin biomass though additional reactants are required to remove all lignin in high-lignin biomass [17]. Alkali pretreatments improve the theoretical sugar yield compared with acid pretreatments and so there is a recent increase in focus 
using this treatment to optimise polysaccharide retention [19]. Thus, both pretreatment processes are of interest to future bioenergy systems.

A number of researchers have conducted studies on Miscanthus for sugar release and conversion to ethanol using dilute acid [20], alkali [21] or both [15, 22, 23], sometimes as a two-step procedure [24]. Within these studies different emphases have been put on the Miscanthus composition and its role in data interpretation. The majority of yeasts use glucose predominantly or exclusively over C5 sugars such as xylose and arabinose so cellulose availability and degradability are of greater importance in current lignocellulosic biofuel studies, though this is changing. Crystalline cellulose is the main form of cellulose and is created through hydrogen bonds between different layers of glucose polymeric chains and the van der Waals forces between parallel chains [23]. A small proportion occurs as amorphous cellulose and it is more susceptible to hydrolysis in this state [11]. Investigations into cellulose crystallinity and the effect of milling Miscanthus on subsequent sugar hydrolysis yields following enzymic degradation showed smaller particle-sized fractions of ball-milled Miscanthus had reduced crystalline cellulose in them compared with larger particlesized fractions. There was also a corresponding increase in glucose release following enzyme addition [25]. Other work determined that lower levels of cellulose crystallinity occurred in Miscanthus accessions with high hemicellulose and higher levels in those with high cellulose or lignin proportions. This was an important factor as to why Miscanthus with a relatively high hemicellulose content showed high biomass degradation following acid or alkali pretreatments. In contrast, high cellulose or lignin proportions led to lower biomass saccharification occurring, particularly after the acid pretreatment [22]. The reason why high hemicellulose proportions affects the crystallinity of the cellulose was proposed by [15], who in their characterisation studies found that the arabinose substitution degree in the xylan was a key factor relating to degradability following acid and alkali pretreatments. Arabinose is partially associated with amorphous cellulose, so higher levels of arabinose indicated higher amorphous cellulose and, therefore, improved sugar release from the biomass. Cellulose crystallinity can also be reduced through enhancing lignin removal from the biomass through alkali addition which in turn alters the crystallinity of the cellulose [24]. Supporting this, [26] showed that following an alkali pretreatment there was an inverse relationship between lignin content and enzyme hydrolysis yields, making lignin not hemicellulose the main target of the pretreatment.

The most recent review summarising the work surrounding the use of Miscanthus for bioethanol production to date is by [27]. They recognise that in addition to the different pretreatments, enzyme saccharifications and ethanol yields are obtained by groups worldwide in this area; the species, cultivation and composition of the Miscanthus plants are highly important. A relevant recent article by [28] looked at the main components of plant cells to aid in selection for a range of energy crops, concluding that cellulose content was the main factor in ethanol production.

Following the work of [27] and expanding that of [28], in this study we combine pretreatments and species of variable composition, making it to our knowledge the only manuscript which both uses material from highlycharacterised Miscanthus lines for conducting dilute acid and alkali pretreatments with complementary hydrothermal pretreatments; and following enzyme hydrolysation produces bioethanol. This study took the known cellulose, hemicellulose and lignin proportions for these samples and calculated the H:L ratio. This was used as a criteria for selecting the analysed Miscanthus accessions. Following saccharification alone or pretreatments with acid, alkali or hot water, the glucose and xylose yields were determined from samples taken from pre- and postenzyme saccharification, with arabinose and ethanol yields also measuring following fermentation. Sampling throughout the experiment has provided insights into the efficacy of the pretreatments themselves and their effect on both subsequent enzyme degradation and ethanol production. This in turn has enabled correlation coefficients to be generated, to examine whether the H:L ratio or other cell wall components are viable indicators for Miscanthus digestibility and ethanol production. Insights from this work can be used to aid future Miscanthus selection for biochemical conversion.

\section{Methods}

\section{Miscanthus lines}

A collection of 244 different Miscanthus genotypes accrued from smaller collections across Europe including those with known origins in China, Japan and South Korea were planted at IBERS, Aberystwyth, in spring 2005 . The collection consists of $187 \times M$. sinensis, $35 \times M$. sacchariflorus and $22 \times M$. hybrids, predominantly $M . x$ giganteus [2]. In February 2008, material was harvested and milled using a modified silage maize harvester. Samples were dried for $18-24 \mathrm{~h}$ at $60^{\circ} \mathrm{C}$ then ground through a 1-mm mesh using a hammer mill [3]. A number of analyses have previously been conducted on this material including Neutral Detergent Fibre (NDF), Acid Detergent Fibre (ADF) and Acid Detergent Lignin (ADL), which with ash measurements informed on the proportion of hemicellulose, cellulose and lignin present in each sample [3]. 20 Miscanthus genotypes were selected from these 
accessions using this available composition data and randomly designated $1-20$. Selected genotypes included the three different species (M. giganteus, M. sacchariflorus, $M$. sinensis); and consisted of those with relatively high, intermediate and low holocellulose to lignin ratio contents.

\section{Enzymic saccharification of non-pretreated Miscanthus samples}

Enzymic saccharification was conducted as described in [29]. Briefly, $150 \mathrm{mg}$ dry weight milled Miscanthus from four biological replicates of the 20 selected genotypes were weighed out in quadruplicate into screwcap glass boiling tubes. Each reaction volume of $10 \mathrm{~mL}$ contained sodium citrate buffer $(50 \mathrm{mM})$ and sodium azide $(0.02 \%)$ with duplicate tubes run with and without enzyme preparations providing approximately $60 \mathrm{FPU} \mathrm{g}^{-1}$ cellulase and $64 \mathrm{pNPGU} \mathrm{g}^{-1} \beta$-glucosidase with additional xylanase at approximately $2500 \mathrm{ABXU} \mathrm{g}{ }^{-1}$ xylanase. These were sourced from "mixed cellulase" in Novozymes' cellulosic ethanol kit vial A (Novozymes), Accellerase 1500 and Accellerase XY (Genencor), respectively. This equated to $2 \times 100 \mu \mathrm{L}$ aliquot additions of 1 ) Novozyme vial A at a 6 in 7 dilution and 2) Accellerase 1500 and Accellerase $\mathrm{XY}$ together, both prepared at a 1 in 10 dilution. Boiling tubes were screwed tight and incubated horizontally at $50{ }^{\circ} \mathrm{C} \pm 1{ }^{\circ} \mathrm{C}$ for $168 \mathrm{~h}$ at $130 \mathrm{rpm}$ (Gallenkamp shaking incubator). An aliquot of $0.5 \mathrm{~mL}$ was removed from each tube following incubation, heated to $100{ }^{\circ} \mathrm{C}$ for $10 \mathrm{~min}$ then cooled to room temperature before storing at $-20{ }^{\circ} \mathrm{C}$ prior to sugar analyses.

\section{Glucose and xylose determination for non-pretreated samples}

Glucose and xylose concentrations of the saccharified Miscanthus were determined using D-glucose (GOPOD) and D-xylose assay kits (Megazyme, Bray, Ireland) with the GOPOD assay run at a 1:10 scale and the D-xylose run at microplate scale.

\section{Severity factor calculations}

The $R_{0}$ severity factor was determined as described by [30] based on initial definitions by [31]. $R_{0}=t^{*} \exp [T-100 / 14.75]$ where $t=$ time in minutes and $T=$ temperature in ${ }^{\circ} \mathrm{C}$.

\section{Acid pretreatment}

The acid pretreatment was based on previous acid treatment studies [32]. $3.0 \mathrm{~g}$ dry solid-ground Miscanthus was added to 60 - $\mathrm{mL}$ boiling tubes with screwcap lids. Duplicate samples had $20 \mathrm{~mL} 1 \% \mathrm{H}_{2} \mathrm{SO}_{4}(\mathrm{w} / \mathrm{w})$ added to a second set of duplicate tubes containing $20 \mathrm{~mL}$ deionised water (the mild water pretreatment).
All tubes were vortexed and autoclaved at $111{ }^{\circ} \mathrm{C}$ for 30 min with loose lids. Following autoclaving, tubes were cooled to room temperature by incubating in cold water then sampled. A $1 \mathrm{~mL}$ aliquot was removed and stored at $-20{ }^{\circ} \mathrm{C}$ prior to analysis.

An additional $5 \mathrm{~mL}$ was then added to each tube of $0.4 \mathrm{M} \mathrm{Ca}(\mathrm{OH})_{2}$ (acid pretreatment samples) or $5.0 \mathrm{~mL}$ deionised water (water controls). This generated a $\mathrm{pH}$ of approximately 5.0 in each tube following thorough mixing using a clean wire loop.

\section{Alkali pretreatment}

Alkali pretreatment was based on previous work by [18] with a reduced biomass loading to match that used in the acid pretreatment and to enable sample mixing. $3.0 \mathrm{~g}$ dry solid-ground Miscanthus was added to $60-\mathrm{mL}$ boiling tubes with screwcap lids. Duplicate samples had $20 \mathrm{~mL}$ $0.2 \mathrm{M} \mathrm{Ca}(\mathrm{OH})_{2}$ added with a second set of duplicate tubes containing $20 \mathrm{~mL}$ deionised water (the severe water pretreatment).

All tubes were vortexed and autoclaved at $120{ }^{\circ} \mathrm{C}$ for $4 \mathrm{~h}$ with loose lids. Following autoclaving, tubes were cooled to room temperature by incubating in cold water then sampled. A $1 \mathrm{~mL}$ aliquot was removed and stored at $-20^{\circ} \mathrm{C}$ prior to analysis.

An additional volume was added to each tube of either $5 \mathrm{~mL} 5 \%(\mathrm{w} / \mathrm{w}) \mathrm{H}_{2} \mathrm{SO}_{4}$ (alkali pretreatment samples) or $5.0 \mathrm{~mL}$ deionised water (water controls). This generated a $\mathrm{pH}$ of approximately 5.0 in each tube following thorough mixing using a clean wire loop.

\section{Enzyme treatment for pretreated samples}

A $0.8 \mathrm{~mL}$ enzyme cocktail containing Genencor enzymes Accellerase $1500\left(125 \mu \mathrm{L} \mathrm{g}^{-1}\right.$ biomass $)$ and Accellerase $\mathrm{XY}\left(50 \mu \mathrm{L} \mathrm{g}^{-1}\right.$ biomass) was added to each tube following the pretreatment and $\mathrm{pH}$ adjustments. Tubes were vortexed thoroughly then incubated horizontally with tight lids to maximise enzyme mixing at $50{ }^{\circ} \mathrm{C}, 150 \mathrm{rpm}$ for $72 \mathrm{~h}$. Following incubation, $1 \mathrm{~mL}$ was removed into a microcentrifuge tube, heated to $100{ }^{\circ} \mathrm{C}$ for $10 \mathrm{~min}$ in a hot block, cooled and frozen for further analysis.

\section{Fermentation treatment}

A $0.5 \mathrm{~mL}$ aliquot of a recently prepared 1 in 10 (w/v) Ethanol Red yeast (Fermentis, Marcq-en-Baroeul, France) solution was prepared based on the method in [33] and was used to inoculate each tube. Each tube was briefly vortexed, then incubated at $30{ }^{\circ} \mathrm{C}$ with loose lids for $48 \mathrm{~h}$ with $1 \mathrm{~mL}$ sample taken at termination. All samples were boiled at $100{ }^{\circ} \mathrm{C}$ for $10 \mathrm{~min}$, cooled and frozen prior to analysis. 


\section{YSI analysis}

A YSI 2700 Select Biochemistry Analyzer (YSI Incorporated, Yellow Springs, OH, USA) was used with glucose and xylose membranes to give selective values for these sugars in the samples taken following the pretreatments and enzyme treatments. The concentrations were calculated using 2700 Xylose PC software LabVIEW 8.5 (YSI Inc.) with subsequent compilations and calculations conducted in Excel (Microsoft Office Professional Plus 2013, Microsoft Redmond, WA, USA).

\section{High-performance liquid chromatography analysis}

To analyse the fermentation products, high-performance liquid chromatography (HPLC) was used based on the method described by [33]. Solutions to be analysed were diluted with $5 \mathrm{mM} \mathrm{H}_{2} \mathrm{SO}_{4}$ containing $5 \mathrm{mM}$ crotonic acid as an internal standard. The mixture was filtered through a $0.45-\mu \mathrm{m}$ Duropore (PVDF) filtre (Millex-HV, Millipore, USA) and run on a Resex ROA-organic acid $\mathrm{H}+$ column at $35{ }^{\circ} \mathrm{C}$ with $5 \mathrm{mM} \mathrm{H}_{2} \mathrm{SO}_{4}$ as the mobile phase at $0.6 \mathrm{~mL} \mathrm{~min}^{-1}$ (Jasco, UK). Concentrations of compounds of interest were determined by refractive index detector and the HPLC software (EZChrom Elite version 3.2, Scientific Software, Agilent Technologies, USA) calibrated with a range of standards. Further calculations were subsequently carried out in Excel (Microsoft).

\section{Statistical analysis}

Data were initially manipulated using Excel (Microsoft), then analysed in IBM SPSS v 23 (IBM Corp) using Multivariate General Linear Model to produce MANOVAs including post hoc Tukey HSD multiple comparison and bivariate correlations generated using Pearson's productmoment correlation coefficient.

\section{Results}

Miscanthus feedstock

Twenty selected Miscanthus accessions repeated in four adjacent Miscanthus trial plots (biological replicates 1-4) were harvested concurrently, weighed, and a subsample was dried and milled. A summary table based on dry solids (DS) detailing the Miscanthus species, average $\mathrm{H}: \mathrm{L}$ ratio and composition fractions are presented in Table 1. The composition differences between the highest and lowest lignin and hemicellulose values were 58.9 and $68.7 \mathrm{~g} \mathrm{kgDS}^{-1}$, respectively, in contrast to cellulose where the difference was $131.6 \mathrm{~g} \mathrm{kgDS}^{-1}$, showing approximately $\times 2$ greater distribution of the cellulose

Table 1 Holocellulose to lignin ratio and composition for selected Miscanthus accessions

\begin{tabular}{|c|c|c|c|c|c|c|c|}
\hline $\begin{array}{l}\text { Miscanthus } \\
\text { accession }\end{array}$ & $\begin{array}{l}\text { Accession title } \\
\text { in second study (if } \\
\text { applicable) }\end{array}$ & Putative species & $\mathrm{H}:$ L ratio & Lignin $\left(\mathrm{g} \mathrm{kg}^{-1} \mathrm{DS}\right)$ & Cellulose $\left(\mathrm{g} \mathrm{kg}^{-1} \mathrm{DS}\right)$ & $\begin{array}{l}\text { Hemicellulose } \\
\left(\mathrm{g} \mathrm{kg}^{-1} \mathrm{DS}\right)\end{array}$ & $\begin{array}{l}\text { Holocellulose } \\
\left.\text { ( } \mathrm{g} \mathrm{kg}^{-1} \mathrm{DS}\right)\end{array}$ \\
\hline 1 & High 1 & sinensis & 10.3 & 68.7 & 370.2 & 335.7 & 705.9 \\
\hline 2 & & sinensis & 9.6 & 76.1 & 395.0 & 336.9 & 731.9 \\
\hline 3 & High 2 & sacchariflorus & 9.0 & 77.7 & 370.1 & 330.1 & 700.2 \\
\hline 4 & High 3 & sinensis & 9.0 & 91.2 & 461.8 & 354.0 & 815.8 \\
\hline 5 & & sinensis & 8.7 & 92.6 & 458.6 & 346.0 & 804.6 \\
\hline 6 & & sinensis & 8.6 & 92.8 & 452.5 & 341.2 & 793.7 \\
\hline 7 & & sinensis & 8.4 & 92.4 & 437.6 & 332.8 & 770.3 \\
\hline 8 & & sinensis & 8.0 & 96.4 & 446.0 & 323.9 & 769.9 \\
\hline 9 & & sinensis & 7.9 & 100.0 & 447.1 & 339.2 & 786.4 \\
\hline 10 & & sacchariflorus & 7.9 & 97.5 & 424.2 & 333.5 & 757.7 \\
\hline 11 & Medium 1 & sinensis & 7.7 & 105.9 & 474.9 & 334.3 & 809.2 \\
\hline 12 & Medium 2 & sinensis & 7.6 & 104.8 & 459.6 & 338.6 & 798.1 \\
\hline 13 & Medium 3 & sacchariflorus & 7.5 & 102.9 & 447.5 & 317.4 & 764.8 \\
\hline 14 & & giganteus & 7.4 & 106.3 & 462.1 & 325.5 & 787.6 \\
\hline 15 & & giganteus & 6.9 & 113.5 & 482.6 & 291.9 & 774.5 \\
\hline 16 & & sinensis & 6.6 & 114.8 & 472.5 & 286.0 & 758.5 \\
\hline 17 & & sacchariflorus & 6.5 & 120.8 & 470.1 & 317.6 & 787.7 \\
\hline 18 & Low 1 & giganteus & 6.3 & 124.6 & 500.1 & 283.2 & 783.2 \\
\hline 19 & Low 2 & sacchariflorus & 6.1 & 125.8 & 475.2 & 295.2 & 770.4 \\
\hline 20 & Low 3 & sacchariflorus & 6.0 & 127.6 & 449.3 & 318.4 & 767.6 \\
\hline Range & & & $6.0-10.3$ & $68.7-127.6$ & $370.1-500.1$ & $283.2-354.0$ & $700.2-815.8$ \\
\hline Mean & & & 7.8 & 101.6 & 447.8 & 324.1 & 771.9 \\
\hline
\end{tabular}

H:L holocellulose to lignin ratio, DS dry solids 
proportion than within the other main cell wall components. Much of the variation in the holocellulose to lignin ratio can, therefore, be attributed to the cellulose fraction of the holocellulose rather than the hemicellulose or lignin fractions.

\section{No pretreatment saccharification assay}

Each bag containing a non-pretreated Miscanthus accession replicate (biological replicate) was sampled four times, with two technical replicates incubated with additional enzymes and two technical replicates incubated without as controls. Randomly ordered batches of these samples were incubated, following which analysis was conducted to quantify the glucose and xylose released from each sample per gram dry solids. Figure 1 shows the glucose released from each biological replicate with and without enzyme additions against the H:L ratio. Trend lines added for each data set show a general increase in glucose as the H:L ratio increases $(y=9.20 x-31.98$, $R^{2}=0.48 ; y=4.98 x-30.46, R^{2}=0.41$ for values with and without enzyme added, respectively).

Overall, there was a significant difference between biological replicates incubated with enzymes $(P \leq .05)$, with Tukey test analysis showing glucose release from biological replicate 1 was significantly higher $(P \leq .01)$ than replicate 2 though not significantly different from biological replicates 3 and 4. These are shown in Table 2 as mean sugars released and significant differences between replicates are denoted by different lower case letters. There was no significant difference between any of the biological replicates incubated without enzyme additions.

Figure 2 shows the xylose release determined concurrently with the glucose release. Tukey analysis showed

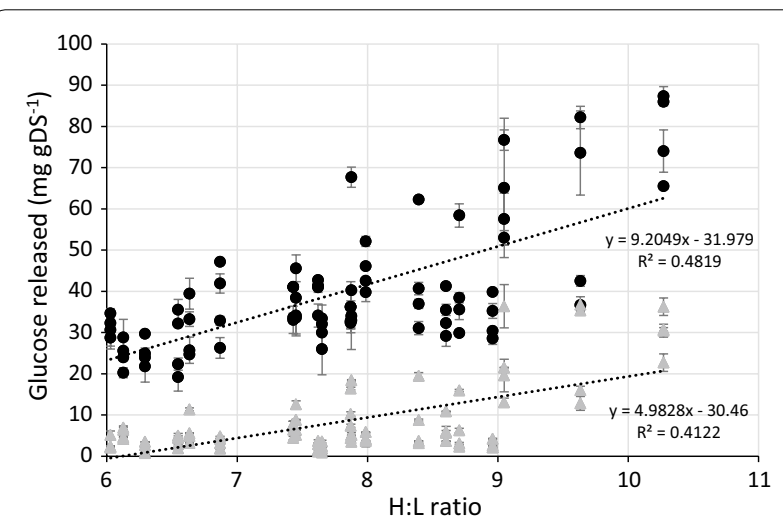

Fig. 1 Glucose release from four biological replicates of selected Miscanthus accessions following incubation with and without mixed enzyme addition. Black circles = biological replicate incubated with enzymes; grey triangles $=$ biological replicates incubated without enzyme addition. $n=2$, error bars show standard deviation
Table 2 Glucose and xylose released from selected Miscanthus accessions following incubation with and without added enzymes (xylose with enzyme only), separated into replicate plots

\begin{tabular}{|c|c|c|c|}
\hline \multirow[t]{2}{*}{ Replicate } & \multicolumn{2}{|c|}{ Glucose released $\left(\mathrm{mg} \mathrm{gDS}^{-1} \pm \mathrm{sd}\right)$} & \multirow{2}{*}{$\begin{array}{l}\text { Xylose released } \\
\left.\text { (mg gDS }{ }^{-1} \pm \mathrm{sd}\right) \\
\text { Enzyme addition }\end{array}$} \\
\hline & Enzyme addition & No enzymes & \\
\hline 1 & $44.62 \pm 19.78 b$ & $10.44 \pm 9.76 \mathrm{a}$ & $9.15 \pm 2.27 \mathrm{a}$ \\
\hline 2 & $33.82 \pm 11.12 \mathrm{a}$ & $7.37 \pm 6.09 a$ & $9.51 \pm 2.18 \mathrm{a}$ \\
\hline 3 & $41.69 \pm 14.72 a b$ & $6.64 \pm 9.51 \mathrm{a}$ & $9.01 \pm 2.41 \mathrm{a}$ \\
\hline 4 & $39.14 \pm 13.57 a b$ & $9.16 \pm 9.89 a$ & $9.62 \pm 1.32 \mathrm{a}$ \\
\hline
\end{tabular}

$n=40$ for each value given. Different lower case letters denote significant differences between treatments calculated using Tukey HSD

DS dry solids, sd standard deviation

no significant difference $(P>.05)$ between the four biological replicates incubated with enzyme (Table 2) and there was no alteration of xylose release dependent on the $\mathrm{H}: \mathrm{L}$ ratio as seen by the generated trend line in Fig. $2\left(y=0.28 x+7.11, R^{2}=0.03\right)$. All untreated samples had a xylose concentration of $<2 \mathrm{mg} \mathrm{gDS}^{-1}$, considered below viable quantification in this study.

To carry out a more in-depth analysis, one replicate was selected for a subsequent trial. Replicate 2 has previously been shown [2] to repeatedly give consistent higher biomass yields in the field than the other replicates and so was selected for further study. From replicate 2 , nine accessions were studied in greater depth. These covered the range of selected material as before, with relatively high, medium and low holocellulose to lignin ratios (see Table 1 ) and comprised of accessions 1, 3, 4 (High 1-3); 11-13 (Medium 1-3); 18-20 (Low $1-3)$.

\section{Variable pretreatment study}

Duplicate technical replicate samples of the replicate 2 Miscanthus accessions were randomly grouped prior to analyses as before. Samples underwent acid and alkali pretreatment studies with control water preparations undergoing the same autoclaving conditions. Different methodologies were used for the acid and alkali pretreatments with the $\log \mathrm{R}$ severity index calculated for each $[30,31]$. The acid pretreatment had a severity index of 1.35 and the alkali pretreatment of 2.51. The water comparison samples were, therefore, termed mild and severe water treatments for the acid and alkali conditions, respectively; and were studied alongside the $\mathrm{pH}$-altered samples to determine the relative effect of heat treatment alone on the sugar release and subsequent ethanol production from the Miscanthus biomass. 


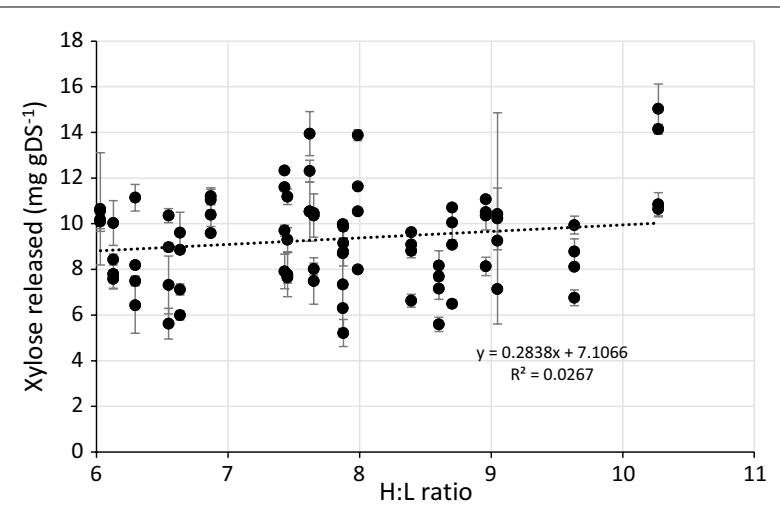

Fig. 2 Xylose release from four biological replicates of selected Miscanthus accessions following incubation with mixed enzyme addition. Black circles = biological replicate incubated with enzymes. Controls without enzyme addition below detectable limit $\left(<2 \mathrm{mg} \mathrm{gDS}^{-1}\right) n=2$, error bars show standard deviation

\section{Pre-and post-enzymic saccharification}

Following the pretreatments, aliquots were removed and analysed for glucose and xylose release. These values are shown in Tables 3 and 4 as "pre-enzyme", with the MANOVA statistical summary relating to Tukey significant differences within Tables 3, 4, 5 and 6 shown in Table 7. Similar values can be seen for glucose release between each pretreatment and the no-enzyme controls in Fig. 1, showing that the pretreatments alone do not release glucose. The alkali glucose pre-enzyme values are not presented in Table 3 as they were below the detectable limit (BDL), most likely due to detector inhibition [34]. BDL concentrations of xylose were similarly detected in all pre-enzyme samples

All samples were then adjusted to $\mathrm{pH} 5.0$ and incubated with a blend of hydrolytic enzymes with activities recommended for lignocellulosic degradation [29] as before. Following incubation, an aliquot of sample was removed to determine the glucose and xylose concentrations as before. Glucose yields, recorded in Table 3 as "post-enzyme", show a large increase in the glucose release (as high as $\times 10$ ) for all accessions compared with the pre-enzyme values. In addition, there is an increase of up to $100 \mathrm{mg} \mathrm{g}^{-1} \mathrm{DS}$ of glucose release in the $\mathrm{pH}$-altered samples compared to the hot water treatment samples. Xylose yields were determined simultaneously with glucose content following enzyme saccharification and are shown in Table 4 as post-enzymic saccharification. As before, these yields have been examined using Tukey HSD multiple comparison analysis and statistically significant differences are shown in Table 3 as different lower case letters; however, the xylose yields showed no clear trends between accessions.

\section{Arabinose release and ethanol production}

Following enzymic degradation, all Miscanthus samples were fermented to produce bioethanol as an example of a bioconversion product. Samples taken after $48 \mathrm{~h}$ were analysed for ethanol and arabinose content in addition to glucose and xylose, with yields of ethanol and arabinose shown in Table 5. Ethanol and arabinose proportions increased in samples with $\mathrm{pH}$-altering pretreatments; though there were fewer significantly different yields than with glucose yields.

Glucose presence was not detected in any post-fermentation samples and the xylose concentrations are comparable to post-enzyme levels shown in Table 4; so neither are shown here. Arabinose was also determined following enzymic saccharification and fermentation as it is a significant part of hemicellulose and is also partially associated with amorphous cellulose [15] potentially impacting glucose saccharification yields, but levels showed no decrease during the fermentation period. This is consistent with previous studies by the authors using Ethanol Red yeast which does not ferment xylose or arabinose (data not shown). As before, Tukey HSD was used to determine significant differences in arabinose and ethanol yields between accessions and is shown in Table 5, through different lowercase letters. There is an increase in arabinose release seen in the acid- and alkalipretreated samples compared to the water pretreatments, but as with the xylose yields, there were no clearly significantly different results for any accession with any of the pretreatments. For the ethanol yields, there was greater clarity, with the acid and alkali pretreatments resulting in higher ethanol yields than the water pretreatments.

\section{Pretreatment comparison and correlation analysis}

As reported above, there was an increase in sugar release and product yield following acid and alkali pretreatments when compared to the hot water treatments. This was explored further through comparisons of treatment means with Table 6 below clearly showing significantly higher yields for both sugars and ethanol in the acid and alkali pretreatments compared to the hot water treatments. The sequence order for average yields is consistently: 'mild' water<'severe' water <acid pretreatment $<$ alkali pretreatment. Significant differences for yields are seen between the water (not significantly different from each other), and acid and alkali pretreatments for all products except ethanol, where severe water was not significantly different to the acid pretreatment, though it was lower.

To explore the relationships between composition, release of sugars and ethanol production further, Pearson's product-moment correlation was used to generate coefficients between each variable. Previously proposed 


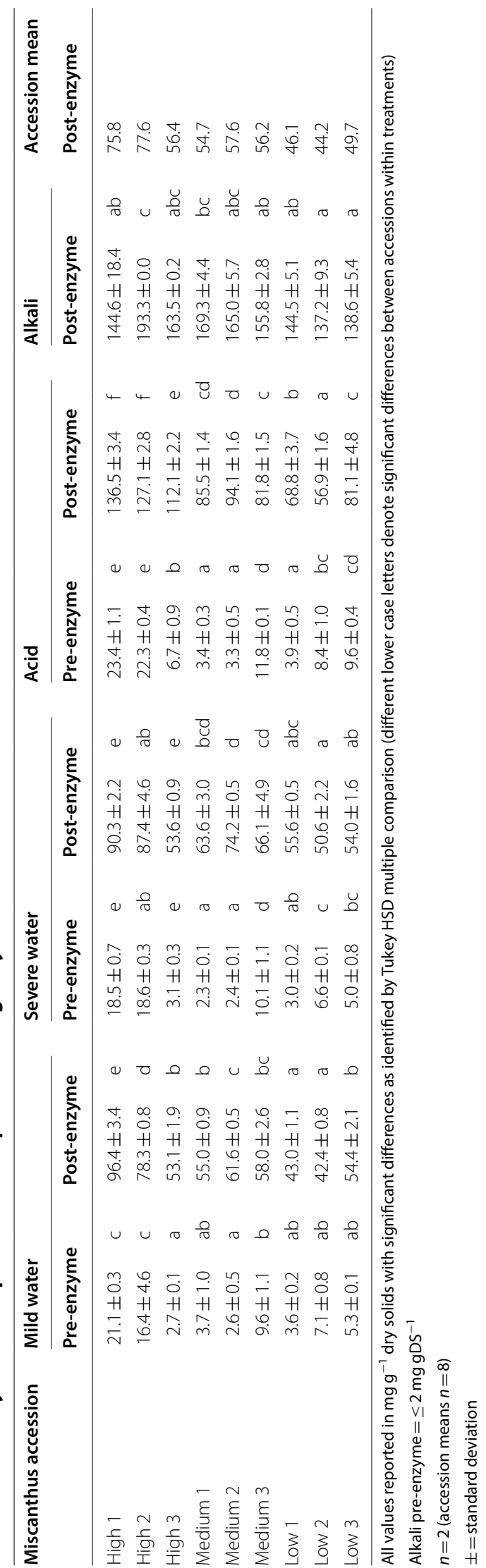


Table 4 Xylose yields from pretreated samples following enzymic saccharification

\begin{tabular}{|c|c|c|c|c|c|c|c|c|c|c|c|}
\hline \multirow[t]{2}{*}{ Miscanthus accession } & \multirow{2}{*}{\multicolumn{2}{|c|}{$\begin{array}{l}\text { Mild water } \\
\text { Post-enzyme }\end{array}$}} & \multirow{2}{*}{\multicolumn{2}{|c|}{$\begin{array}{l}\text { Severe water } \\
\text { Post-enzyme }\end{array}$}} & \multicolumn{4}{|l|}{ Acid } & \multirow{2}{*}{\multicolumn{2}{|c|}{$\begin{array}{l}\text { Alkali } \\
\text { Post-enzyme }\end{array}$}} & \multirow{3}{*}{$\begin{array}{l}\text { Accession mean } \\
\text { Post-enzyme } \\
54.6\end{array}$} \\
\hline & & & & & \multicolumn{2}{|l|}{ Pre-enzyme } & \multicolumn{2}{|c|}{ Post-enzyme } & & & \\
\hline High 1 & $19.6 \pm 0.1$ & e & $23.0 \pm 2.2$ & $a b$ & $24.1 \pm 4.6$ & $a b$ & $95.0 \pm 6.9$ & $b$ & $111.0 \pm 12.4$ & a & \\
\hline High 2 & $16.4 \pm 0.0$ & $c d$ & $23.8 \pm 2.0$ & $\mathrm{a}$ & $18.4 \pm 1.8$ & $a b$ & $74.0 \pm 2.5$ & $\mathrm{a}$ & $107.8 \pm 4.6$ & $a$ & 48.1 \\
\hline High 3 & $15.1 \pm 0.5$ & $\mathrm{bc}$ & $16.9 \pm 1.0$ & $a b$ & $97.4 \pm 13.1$ & C & $155.5 \pm 2.8$ & $d$ & $139.3 \pm 3.6$ & $b$ & 84.8 \\
\hline Medium 1 & $15.8 \pm 0.9$ & bcd & $21.7 \pm 0.2$ & $a b$ & $38.0 \pm 5.3$ & $a b$ & $93.6 \pm 4.9$ & $b$ & $139.9 \pm 7.9$ & $b$ & 61.8 \\
\hline Medium 2 & $17.5 \pm 0.3$ & de & $28.0 \pm 0.9$ & $b$ & $40.2 \pm 10.1$ & $b$ & $111.5 \pm 2.5$ & C & $136.4 \pm 1.3$ & $b$ & 66.7 \\
\hline Medium 3 & $11.3 \pm 0.5$ & $\mathrm{a}$ & $22.1 \pm 3.5$ & $a b$ & $13.5 \pm 0.1$ & $a b$ & $61.9 \pm 1.4$ & a & $124.2 \pm 7.3$ & $a b$ & 46.6 \\
\hline Low 1 & $10.8 \pm 0.2$ & a & $19.9 \pm 2.1$ & $a b$ & $12.5 \pm 0.6$ & a & $62.3 \pm 1.3$ & a & $112.7 \pm 1.6$ & a & 43.6 \\
\hline Low 2 & $13.6 \pm 0.1$ & $b$ & $24.9 \pm 3.3$ & $a b$ & $28.2 \pm 10.4$ & $a b$ & $75.7 \pm 3.5$ & a & $130.7 \pm 1.7$ & $a b$ & 54.6 \\
\hline Low 3 & $17.7 \pm 1.2$ & de & $18.9 \pm 1.8$ & $\mathrm{a}$ & $86.0 \pm 0.4$ & C & $125.9 \pm 4.7$ & C & $126.4 \pm 2.4$ & $a b$ & 75.0 \\
\hline
\end{tabular}

All values reported in $\mathrm{mg} \mathrm{g}^{-1}$ dry solids with significant differences as identified by Tukey HSD multiple comparison (different lower case letters denote significant differences between accessions within treatments)

Mild water, severe water and alkali pre-enzyme values not shown as $=\leq 2 \mathrm{mg} \mathrm{gDS}^{-1}$

$n=2$ (accession means $n=8$ )

$\pm=$ standard deviation

Table 5 Arabinose and ethanol yields from pretreated samples following fermentation

\begin{tabular}{|c|c|c|c|c|c|c|c|c|c|}
\hline Miscanthus accession & Mild water & & Severe wate & & Acid & & Alkali & & $\begin{array}{l}\text { Accession } \\
\text { mean }\end{array}$ \\
\hline \multicolumn{10}{|c|}{ Arabinose yields \pm standard deviation ( $\mathrm{mg} \mathrm{g}^{-1}$ dry solids) } \\
\hline High 1 & $21.0 \pm 2.7$ & $b$ & $25.8 \pm 1.4$ & $b$ & $33.4 \pm 6.8$ & a & $55.6 \pm 3.5$ & 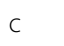 & 34.0 \\
\hline High 2 & $14.1 \pm 3.4$ & $a b$ & $24.3 \pm 6.3$ & $\mathrm{ab}$ & $35.6 \pm 2.3$ & a & $37.8 \pm 2.8$ & $a b c$ & 27.9 \\
\hline High 3 & $15.0 \pm 2.7$ & $a b$ & $19.5 \pm 1.4$ & $a b$ & $33.5 \pm 5.5$ & $a$ & $43.4 \pm 9.3$ & $b c$ & 27.9 \\
\hline Medium 1 & $13.8 \pm 0.9$ & $a b$ & $17.5 \pm 0.3$ & $a b$ & $27.5 \pm 2.3$ & $a$ & $34.2 \pm 2.3$ & $a b$ & 23.2 \\
\hline Medium 2 & $14.7 \pm 1.1$ & $a b$ & $17.9 \pm 0.2$ & $a b$ & $29.0 \pm 2.9$ & a & $34.4 \pm 3.1$ & $a b$ & 24.0 \\
\hline Medium 3 & $13.0 \pm 2.1$ & $\mathrm{a}$ & $17.0 \pm 0.8$ & $a b$ & $27.6 \pm 1.9$ & a & $33.6 \pm 2.5$ & $a b$ & 22.8 \\
\hline Low 1 & $12.9 \pm 0.4$ & $\mathrm{a}$ & $16.1 \pm 1.3$ & a & $26.1 \pm 2.5$ & $a$ & $29.3 \pm 1.4$ & $a b$ & 21.1 \\
\hline Low 2 & $13.7 \pm 0.2$ & $a b$ & $15.8 \pm 1.0$ & $\mathrm{a}$ & $21.0 \pm 1.7$ & $a$ & $19.9 \pm 7.5$ & $\mathrm{a}$ & 17.6 \\
\hline Low 3 & $16.2 \pm 0.9$ & $a b$ & $20.6 \pm 0.8$ & $a b$ & $30.8 \pm 6.6$ & a & $46.0 \pm 3.7$ & $b c$ & 28.4 \\
\hline \multicolumn{10}{|c|}{ Ethanol yields \pm standard deviation ( $\mu \mathrm{L} \mathrm{g}^{-1}$ dry solids) } \\
\hline High 1 & $64.9 \pm 3.2$ & $d$ & $46.1 \pm 9.2$ & $a b$ & $105.0 \pm 5.3$ & g & $101.7 \pm 0.7$ & $a b c$ & 79.4 \\
\hline High 2 & $36.7 \pm 4.9$ & $c$ & $77.8 \pm 6.9$ & a & $55.7 \pm 4.0$ & de & $151.4 \pm 9.6$ & $d$ & 80.4 \\
\hline High 3 & $27.9 \pm 0.4$ & $a b c$ & $28.2 \pm 0.6$ & $c$ & $74.0 \pm 2.4$ & $f$ & $93.6 \pm 5.3$ & $a b$ & 56.0 \\
\hline Medium 1 & $17.5 \pm 2.1$ & $\mathrm{a}$ & $45.0 \pm 3.0$ & $a b$ & $36.6 \pm 2.9$ & $b c$ & $119.3 \pm 10.6$ & $c$ & 54.6 \\
\hline Medium 2 & $14.9 \pm 1.5$ & $a$ & $50.9 \pm 3.8$ & $b$ & $44.3 \pm 2.7$ & $\mathrm{~cd}$ & $121.9 \pm 7.7$ & c & 58.0 \\
\hline Medium 3 & $19.0 \pm 9.9$ & $a b$ & $49.5 \pm 7.4$ & $b$ & $37.0 \pm 3.5$ & $b c$ & $114.3 \pm 2.3$ & $b c$ & 54.9 \\
\hline Low 1 & $14.1 \pm 0.5$ & $a$ & $35.1 \pm 3.4$ & $a b$ & $28.3 \pm 0.7$ & $a b$ & $99.0 \pm 1.7$ & $a b c$ & 44.1 \\
\hline Low 2 & $12.4 \pm 4.2$ & a & $36.8 \pm 5.0$ & $a b$ & $21.7 \pm 1.6$ & a & $103.2 \pm 1.5$ & $a b c$ & 43.5 \\
\hline Low 3 & $34.9 \pm 2.5$ & bc & $30.8 \pm 3.2$ & $a b$ & $57.3 \pm 1.8$ & $\mathrm{e}$ & $85.8 \pm 6.6$ & a & 52.2 \\
\hline
\end{tabular}

All values reported ( $\mathrm{mg}$ and $\mu \mathrm{L} \mathrm{g}^{-1}$ dry solids, respectively) significant differences as identified by Tukey HSD multiple comparison analysis (different lower case letters denote significant differences between treatments)

$n=2$ (accession means $n=8$ )

$\pm=$ standard deviation

cellulose:lignin and cellulose:hemicellulose ratios [35] were also included to enable assessment of these ratios too. Correlation analyses considered the influences for each pretreatment, with Table 8 showing correlations $\geq .70$ which were also highly significant $(P \leq .001)$. A number were to be expected: the H:L ratio was highly 
Table 6 Comparison of different pretreatments on average subsequent product yields $\left(\mathrm{mg} \mathrm{g}^{-1}\right.$ dry solids) $n=18$

\begin{tabular}{|c|c|c|c|c|c|c|c|c|}
\hline Treatment mean & Post-en & cose & Post-e & ose & Post- $\epsilon$ & abinose & Ethanol & \\
\hline Mild water & 60.24 & a & 15.29 & $\mathrm{a}$ & 14.93 & a & 26.92 & . \\
\hline Severe water & 66.17 & a & 22.14 & $\mathrm{a}$ & 19.37 & a & 44.48 & $k$ \\
\hline Acid & 93.77 & $b$ & 95.03 & $\mathrm{~b}$ & 29.39 & $b$ & 51.08 & 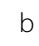 \\
\hline Alkali & 156.86 & c & 125.38 & $c$ & 37.14 & c & 110.02 & \\
\hline
\end{tabular}

Significant differences determined using Tukey HSD and shown by different lower case letters

Table 7 MANOVA showing main effects of genotype and treatment on sugar release and ethanol yield

\begin{tabular}{|c|c|c|c|c|c|c|}
\hline Source & Dependent variable & Sum of squares & df & Mean square & $\mathbf{F}$ & $P \leq$ \\
\hline \multirow[t]{4}{*}{ Genotype } & Glucose & $17,733.386$ & 8 & 2216.673 & 114.390 & .000 \\
\hline & Xylose & 6431.954 & 8 & 803.994 & 58.934 & .000 \\
\hline & Arabinose & 1500.168 & 8 & 187.521 & 15.565 & .000 \\
\hline & Ethanol & $11,367.802$ & 8 & 1420.975 & 60.103 & .000 \\
\hline \multirow[t]{4}{*}{ Treatment } & Glucose & $105,577.129$ & 3 & $35,192.376$ & 1816.078 & .000 \\
\hline & Xylose & $159,380.491$ & 3 & $53,126.830$ & 3894.300 & .000 \\
\hline & Arabinose & 5393.962 & 3 & 1797.987 & 149.238 & .000 \\
\hline & Ethanol & $70,250.768$ & 3 & $23,416.923$ & 990.464 & .000 \\
\hline \multirow[t]{4}{*}{ Genotype * treatment } & Glucose & 7025.210 & 24 & 292.717 & 15.105 & .000 \\
\hline & Xylose & $12,077.095$ & 24 & 503.212 & 36.886 & .000 \\
\hline & Arabinose & 822.883 & 24 & 34.287 & 2.846 & .002 \\
\hline & Ethanol & $13,493.930$ & 24 & 562.247 & 23.781 & .000 \\
\hline \multirow[t]{4}{*}{ Error } & Glucose & 697.616 & 36 & 19.378 & & \\
\hline & Xylose & 491.119 & 36 & 13.642 & & \\
\hline & Arabinose & 433.722 & 36 & 12.048 & & \\
\hline & Ethanol & 851.126 & 36 & 23.642 & & \\
\hline \multirow[t]{4}{*}{ Total } & Glucose & $131,033.340$ & 71 & & & \\
\hline & Xylose & $178,380.660$ & 71 & & & \\
\hline & Arabinose & 8150.735 & 71 & & & \\
\hline & Ethanol & $95,963.626$ & 71 & & & \\
\hline
\end{tabular}

correlated to its components, with lignin as the most significant fraction followed by cellulose and hemicellulose; cellulose also correlated to lignin and holocellulose. For other ratios similar component-related correlations were observed: cellulose:hemicellulose correlated with cellulose, hemicellulose, lignin, the $\mathrm{H}: \mathrm{L}$ ratio and the cellulose:lignin ratio. This latter ratio also correlated with the $\mathrm{H}: \mathrm{L}$ ratio and lignin.

Treatments could be separated into distinct groups, with the alkali pretreatment showing just two highly significant correlations: between post-enzyme xylose and holocellulose; and post-enzyme glucose and ethanol. This latter was a key correlation, with all pretreatments showing a significant correlation between the ethanol and post-enzyme glucose values. For the remaining three pretreatments, observed correlations were primarily based on glucose yields, both before and after enzyme addition. Pre-enzyme glucose correlated significantly with compositional components, such as lignin, cellulose and holocellulose (and cellulose:hemicellulose for the acid pretreatment only), reflecting the main inhibitors to cell wall degradation and the main glucose-generating substrates. Post-enzyme glucose yields also correlated with these components (except the acid pretreatment which did not correlate with holocellulose), but also correlated with the $\mathrm{H}: \mathrm{L}$, cellulose:hemicellulose and cellulose:lignin (not severe water) ratios, pre-enzyme addition glucose and ethanol yields. The last set of correlations were primarily based on the ethanol yield which correlated with $\mathrm{H}: \mathrm{L}$, cellulose:hemicellulose ratios and cellulose for the mild water and acid pretreatments, with the acid pretreatment also correlating to cellulose:lignin and lignin. In addition, arabinose correlated with the cell wall components and cellulose:hemicellulose ratio (severe water pretreatment only), pre- and post-enzyme glucose yields 


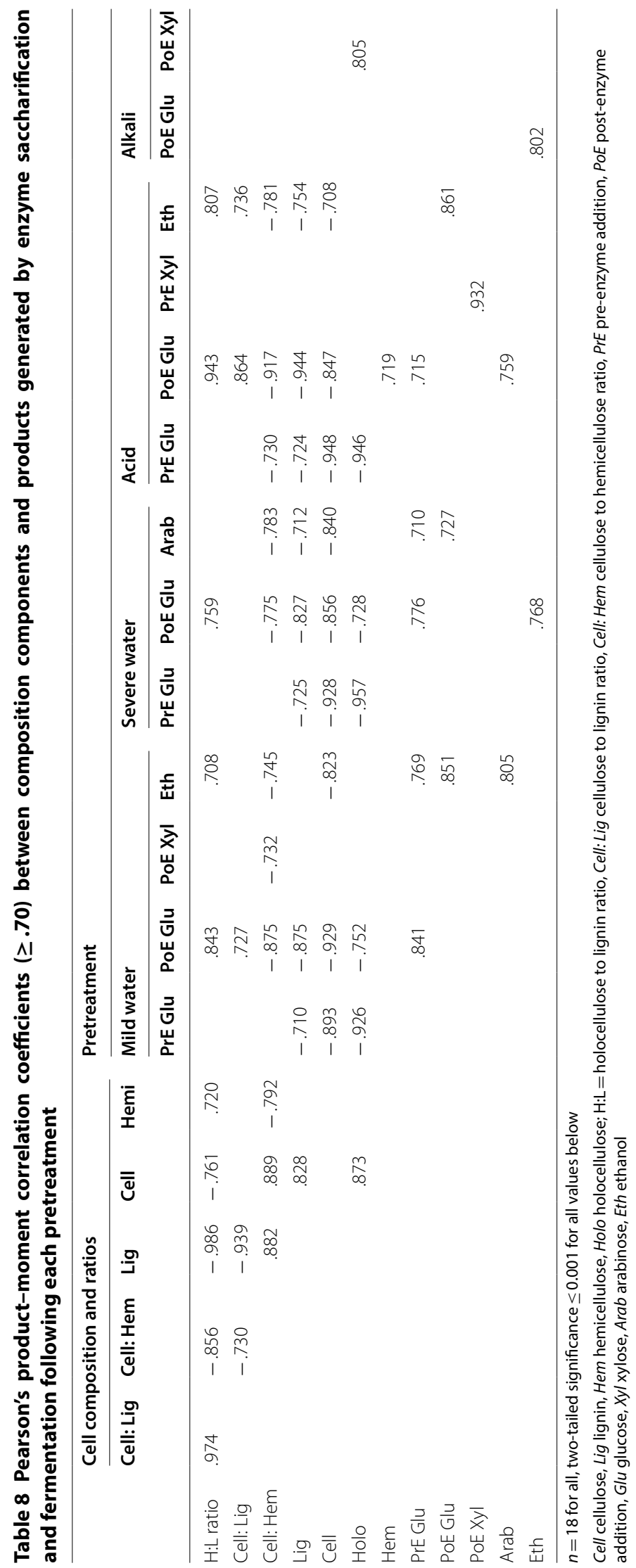


for the severe water pretreatment and post-enzyme glucose (acid pretreatment).

\section{Discussion}

The aim of this research was to assess whether using the $\mathrm{H}: \mathrm{L}$ ratio provided an improved indicator for biological conversion suitability, in particular for biomass degradability and ethanol generation compared with lignin or other cell wall components. This builds on the concept proposed by [14] that the H:L ratio correlates with the relative suitability of Miscanthus for pyrolysis and combustion routes in thermochemical conversion. Similar correlations were identified by [35] for biological conversion who found that ratios of cellulose:lignin and cellulose:xylan could be major determinants of Miscanthus biomass degradability. The Pearson's product of moment correlation coefficient for these ratios with sugar release and ethanol product was determined to assess their potential as indicators too.

Samples of 20 highly-characterised Miscanthus accessions with high, medium and low H:L ratios were analysed for sugar release with and without added enzymes. Following enzyme addition, there was a general trend seen with an increase of glucose release occurring as the $\mathrm{H}: \mathrm{L}$ ratio increased. No such trend was observed for xylose, suggesting that the cellulose proportion of the $\mathrm{H}: \mathrm{L}$ ratio was the key component in the holocellulose fraction regarding lignocellulose degradation.

To investigate this further, a second study was initiated with nine selected accessions undergoing pretreatments prior to enzyme saccharification and conversion to ethanol. Here, the trend relating glucose yield to $\mathrm{H}: \mathrm{L}$ and a lack of correlation with the xylose was repeated. Accessions High 1 and High 2 repeatedly showed significantly higher glucose release yields than the other accessions following pretreatments with acid or hot water produced by 'mild' or 'severe' autoclaving; before and after enzyme addition. These accessions also showed distinct patterns of arabinose release and ethanol production; High 1 gave higher arabinose release than the other accessions, following all pretreatments, but not significantly so. In contrast, for ethanol production there was a clearer split, with High 1 showing significantly higher yields than the other accessions following the mild water and acid pretreatments. High 2 was significantly higher than High 1 for the severe water and alkali-pretreated samples. For both accessions, the yield was considerably higher, with approximately 25 and $50 \mu \mathrm{L}$ more ethanol produced per g DS than the second highest yielder for both water treatments and $\mathrm{pH}$-altered pretreatments, respectively.

Yields of sugar release from the biomass following the hot water pretreatments both before and after enzyme addition were comparable to those seen in Fig. 1 from the first study, where the samples were not pretreated. This suggests that the biomass itself did not alter significantly during the autoclaving process and that structural alteration only occurred at higher temperatures. This reflects that which has been observed in previous studies, for example in the work by [36] where they showed consistent values for glucose yield following enzyme hydrolysis and cellulose fibril crystallinity following hydrothermal reactions between 50 and $155{ }^{\circ} \mathrm{C}$. Above this temperature (assessed to $200{ }^{\circ} \mathrm{C}$ ), fibril crystallinity decreased; glucose yields following enzyme additions increased. In contrast, samples undergoing acid or alkali pretreatments at high temperature did show significant increases in sugar release compared with the water controls and those in the initial study, showing that structural changes occurred.

This is succinctly shown in Table 6 which shows significant differences between pretreatments when the means of all nine accessions are combined. The sequence 'mild water'<'severe water' $<$ acid < alkali pretreatments on glucose, xylose, arabinose and ethanol yields shows that though there was less variation in sugar release and product generation between accessions with the alkali pretreatment, yields were the highest for sugar release and ethanol yields, making this potentially a process to employ on mixed-origin Miscanthus requiring degradation to downstream processing including second-generation biofuels. Conversely, greater variation was seen between accessions with the water and acid pretreatments, which due to their low costs [37] are more likely to be utilised for biochemical conversion routes, and could be a preferred conversion route for characterised Miscanthus with known composition.

A comparative examination of all data values to assess the indicative value of the $\mathrm{H}: \mathrm{L}$ ratio versus lignin or other cell wall component proportion or ratio on sugar and ethanol yields was conducted using Pearson's product of moment correlations (Table 8). Within the table, certain correlations are as predicted. All main cell components showed highly significant correlations with each other, the ratios generated and with the compounds produced, especially those undergoing the acid pretreatment and hot water conditions. The other main correlations were between the glucose yield (particularly post-enzyme saccharification) and ethanol, again unsurprisingly as glucose constituted the almost exclusive substrate for the yeast in this study. Arabinose did correlate, but considering its potential role in indicating cellulose crystallinity its correlations showed no clear pattern and are considered to be indirectly related compared to those above as this sugar is not utilised by the yeast. The correlation with glucose also indicated that the levels of any inhibitors such as furfural and hydroxymethyl furfural which may 
have been generated by the pretreatments were tolerated by the yeast. This is a key concern in the downstream processing of biomass to biofuels as high levels of inhibitors can have a significant effect on the yeast, reducing subsequent yields of bioethanol produced [17]. A second point of concern regarding the pretreatments is that a balance must be struck between the pretreatment severity and product yield. Pretreatments which aggressively remove or redistribute lignin also result in sugar loss through degradation [38]; so this study intentionally used optimal 'mild' acid and alkali pretreatments to minimise the degradation of sugars whilst maximising the differences seen between the Miscanthus genotypes.

\section{Conclusion}

The original objective was to attempt to determine which component or combination (e.g. H:L ratio) is the most accurate for determining sugar release and ethanol yields from Miscanthus. H:L ratios show a higher correlation with ethanol than lignin for mild water and acid-pretreated samples (severe water and alkali-pretreated samples showed $<0.7$ correlation for both $\mathrm{H}: \mathrm{L}$ and lignin); but lignin shows a higher correlation to post-enzyme glucose than $\mathrm{H}: \mathrm{L}$ for both hot waters and acid pretreatments (alkali pretreatment had $<0.7$ correlation) and post-enzyme glucose shows the highest correlation with ethanol following all pretreatments. If the post-enzyme glucose was the focus, then cellulose is the highest correlating cell wall component with post-enzyme glucose and the highest correlating cell wall component with ethanol produced under 'mild water' conditions; we propose that this is used as the predictive component for hot water pretreatments. The H:L ratio correlates most highly to ethanol for the acid pretreatments, but cellulose:hemicellulose, cellulose:lignin, lignin and cellulose also correlate highly. We, therefore, propose that no additional advantage is given through the determination of multiple cell wall components to produce ratios over single cell wall components. We also conclude that in addition to lignin, cellulose alone can be used as a predictor for Miscanthus conversion by glucose-utilising yeast to ethanol following all pretreatments but especially those of hot water and mild acid.

\section{Abbreviations}

BDL: below detectable limit; H:L: holocellulose to lignin ratio; DS: dry solids.

\section{Authors' contributions}

JMMA and EMH selected the 20 Miscanthus accessions used in the study; JMMA and JAG designed the first study reported above; JMMA and ALW designed the second study reported above. EMH did statistical analysis on the data. JMMA was the main writer for the manuscript but all authors has contributed to the final manuscript. All authors read and approved the final manuscript.

\section{Author details}

1 Institute of Biological, Environmental and Rural Sciences, Aberystwyth University, Gogerddan, Aberystwyth SY23 3EE, UK. ${ }^{2}$ Present Address: Hodgson Green \& Associates, Aberystwyth, UK.

\section{Acknowledgements}

The authors wish to acknowledge the supply of compositional data from Dr. Gordon Allison (IBERS, Aberystwyth University).

\section{Competing interests}

The authors declare that they have no competing interests.

\section{Availability of data and materials}

The datasets used and/or analysed during the current study are available from the corresponding author on reasonable request.

\section{Consent for publication}

All authors consent to the publication of this manuscript.

Ethics approval and consent to participate

Not applicable.

Funding

BBSRC (Bioenergy and Biorenewables ISPG, grant code BBS/E/W/10963A01).

\section{Publisher's Note}

Springer Nature remains neutral with regard to jurisdictional claims in published maps and institutional affiliations.

Received: 21 December 2017 Accepted: 2 March 2018

Published online: 14 March 2018

\section{References}

1. Meehan PG, Finnan JM, McDonnell KP. The effect of harvest date and harvest method on the combustion characteristics of Miscanthusxgiganteus. GCB Bioenerg. 2013;5(5):487-96.

2. Robson P, Jensen E, Hawkins S, White SR, Kenobi K, Clifton-Brown J, et al. Accelerating the domestication of a bioenergy crop: identifying and modelling morphological targets for sustainable yield increase in Miscanthus. J Exp Bot. 2013;64(14):4143-55.

3. Allison GG, Morris C, Clifton-Brown J, Lister SJ, Donnison IS. Genotypic variation in cell wall composition in a diverse set of 244 accessions of Miscanthus. Biomass Bioenerg. 2011;35(11):4740-7.

4. Lewandowski I, Clifton-Brown JC, Andersson B, Basch G, Christian DG, Jorgensen $\mathrm{U}$, et al. Environment and harvest time affects the combustion qualities of Miscanthus genotypes. Agron J. 2003:95(5):1274-80.

5. Huyen TLN, Remond C, Dheilly RM, Chabbert B. Effect of harvesting date on the composition and saccharification of Miscanthus $x$ giganteus. Bioresour Technol. 2010;101(21):8224-31.

6. Smith R, Slater FM. Mobilization of minerals and moisture loss during senescence of the energy crops Miscanthus x giganteus, Arundo donax and Phalaris arundinacea in Wales, UK. GCB Bioenerg. 2011;3(2):148-57.

7. Purdy SJ, Cunniff J, Maddison AL, Jones LE, Barraclough T, Castle M, et al. Seasonal carbohydrate dynamics and climatic regulation of senescence in the perennial grass, Miscanthus. Bioenerg Res. 2015:8(1):28-41.

8. Burner DM, Tew TL, Harvey JJ, Belesky DP. Dry matter partitioning and quality of Miscanthus, Panicum, and Saccharum genotypes in Arkansas, USA. Biomass Bioenerg. 2009;33(4):610-9.

9. Hodgson EM, Fahmi R, Yates N, Barraclough T, Shield I, Allison G, et al. Miscanthus as a feedstock for fast-pyrolysis: does agronomic treatment affect quality? Bioresour Technol. 2010;101(15):6185-91.

10. Hodgson EM, Lister SJ, Bridgwater AV, Clifton-Brown J, Donnison IS. Genotypic and environmentally derived variation in the cell wall composition of Miscanthus in relation to its use as a biomass feedstock. Biomass Bioenerg. 2010;34(5):652-60.

11. Kumar P, Barrett DM, Delwiche MJ, Stroeve P. Methods for pretreatment of lignocellulosic biomass for efficient hydrolysis and biofuel production. Ind Eng Chem Res. 2009;48(8):3713-29. 
12. Himmel ME, Ding S-Y, Johnson DK, Adney WS, Nimlos MR, Brady JW, et al. Biomass recalcitrance: engineering plants and enzymes for biofuels production. Science. 2007:315(5813):804-7.

13. Mood SH, Golfeshan AH, Tabatabaei M, Jouzani GS, Najafi G, Gholami M, et al. Lignocellulosic biomass to bioethanol, a comprehensive review with a focus on pretreatment. Renew Sust Energ Rev. 2013;27:77-93.

14. Hodgson EM, Nowakowski DJ, Shield I, Riche A, Bridgwater AV, CliftonBrown JC, et al. Variation in Miscanthus chemical composition and implications for conversion by pyrolysis and thermo-chemical bio-refining for fuels and chemicals. Bioresour Technol. 2011;102(3):3411-8.

15. Li F, Ren S, Zhang W, Xu Z, Xie G, Chen Y, et al. Arabinose substitution degree in xylan positively affects lignocellulose enzymatic digestibility after various $\mathrm{NaOH} / \mathrm{H} 2 \mathrm{SO} 4$ pretreatments in Miscanthus. Bioresour Technol. 2013;130:629-37.

16. Rodrigues CIS, Jackson JJ, Montross MD. A molar basis comparison of calcium hydroxide, sodium hydroxide, and potassium hydroxide on the pretreatment of switchgrass and Miscanthus under high solids conditions. Ind Crop Prod. 2016;92:165-73.

17. Yang F, Liu Z, Afzal W, Liu Z, Bell AT, Prausnitz JM. Pretreatment of Miscanthus giganteus with lime and oxidants for biofuels. Energ Fuel. 2015;29(3):1743-50

18. Kaar WE, Holtzapple MT. Using lime pretreatment to facilitate the enzymic hydrolysis of corn stover. Biomass Bioenerg. 2000;18(3):189-99.

19. Cianchetta S, Bregoli L, Galletti S. Microplate-based evaluation of the sugar yield from giant reed, giant Miscanthus and switchgrass after mild chemical pre-treatments and hydrolysis with tailored trichoderma enzymatic blends. Appl Biochem Biotech. 2017;183(3):876-92.

20. Guo G-L, Chen W-H, Chen W-H, Men L-C, Hwang W-S. Characterization of dilute acid pretreatment of silvergrass for ethanol production. Bioresour Technol. 2008;99(14):6046-53.

21. Kang KE, Chung D-P, Kim Y, Chung B-W, Choi G-W. High-titer ethanol production from simultaneous saccharification and fermentation using a continuous feeding system. Fuel. 2015;145:18-24.

22. Xu N, Zhang W, Ren S, Liu F, Zhao C, Liao H, et al. Hemicelluloses negatively affect lignocellulose crystallinity for high biomass digestibility under $\mathrm{NaOH}$ and $\mathrm{H} 2 \mathrm{SO} 4$ pretreatments in Miscanthus. Biotechnol Biofuels. 2012;5:58.

23. Zhang W, Yi Z, Huang J, Li F, Hao B, Li M, et al. Three lignocellulose features that distinctively affect biomass enzymatic digestibility under $\mathrm{NaOH}$ and $\mathrm{H}_{2} \mathrm{SO}_{4}$ pretreatments in Miscanthus. Bioresour Technol. 2013;130:30-7.

24. Si S, Chen Y, Fan C, Hu H, Li Y, Huang J, et al. Lignin extraction distinctively enhances biomass enzymatic saccharification in hemicelluloses-rich
Miscanthus species under various alkali and acid pretreatments. Bioresour Technol. 2015;183:248-54.

25. Yoshida M, Liu Y, Uchida S, Kawarada K, Ukagami Y, Ichinose H, et al. Effects of cellulose crystallinity, hemicellulose, and lignin on the enzymatic hydrolysis of Miscanthus sinensis to monosaccharides. Biosci Biotech Bioch. 2008;72(3):805-10.

26. de Vrije T, de Haas GG, Tan GB, Keijsers ERP, Claassen PAM. Pretreatment of Miscanthus for hydrogen production by Thermotoga elfii. Int J Hydrogen Energ. 2002:27(11-12):1381-90.

27. Lee W-C, Kuan W-C. Miscanthus as cellulosic biomass for bioethanol production. Biotechnol J. 2015;10(6):840-54.

28. Kikas T, Tutt M, Raud M, Alaru M, Lauk R, Olt J. Basis of energy crop selection for biofuel production: cellulose vs. lignin. Int J Green Energy. 2016;13(1):49-54

29. Selig MN. Weiss, and Y. Ji, Enzymatic Saccharification of Lignocellulosic Biomass. 2008, NREL. NREL/TP-510-42629 8.

30. Garrote G, Dominguez H, Parajo JC. Hydrothermal processing of lignocellulosic materials. Holz Roh Werkst. 1999;57(3):191-202.

31. Overend RP, Chornet E. Fractionation of lignocellulosics by steam-aqueous pretreatments. Phil Trans R Soc Lond A. 1987;321(1561):523-36.

32. Deejing S, Ketkorn W. Comparison of hydrolysis conditions to recover reducing sugar from various lignocellulosic materials. Chiang Mai J Sci. 2009;36(3):384-94.

33. Adams JM, Gallagher JA, Donnison IS. Fermentation study on Saccharina latissima for bioethanol production considering variable pre-treatments. J Appl Phycol. 2009;21(5):569-74.

34. YSI. Personal communication. 2015.

35. Lygin AV, Upton J, Dohleman FG, Juvik J, Zabotina OA, Widholm JM, et al. Composition of cell wall phenolics and polysaccharides of the potential bioenergy crop-Miscanthus. GCB Bioenerg. 2011;3(4):333-45.

36. Ibbett R, Gaddipati S, Hill S, Tucker G. Structural reorganisation of cellulose fibrils in hydrothermally deconstructed lignocellulosic biomass and relationships with enzyme digestibility. Biotechnol Biofuels. 2013;6:33.

37. Kumar AK, Sharma S. Recent updates on different methods of pretreatment of lignocellulosic feedstocks: a review. Bioresour Bioprocess. 2017;4(1):7.

38. Ding SY, Liu YS, Zeng YN, Himmel ME, Baker JO, Bayer EA. How does plant cell wall nanoscale architecture correlate with enzymatic digestibility? Science. 2012;338(6110):1055-60.

\section{Submit your next manuscript to BioMed Central and we will help you at every step:}

- We accept pre-submission inquiries

- Our selector tool helps you to find the most relevant journal

- We provide round the clock customer support

- Convenient online submission

- Thorough peer review

- Inclusion in PubMed and all major indexing services

- Maximum visibility for your research

Submit your manuscript at www.biomedcentral.com/submit
() Biomed Central 